\title{
Quality-of-Life Assessment
}

National Cancer Institute

\section{Source}

National Cancer Institute. Quality-of-Life Assessment. NCI Thesaurus. Code C15584.

A determination of an individual's sense of well-being and ability to enjoy life. 